\title{
Microbiology of a high energy beach sediment: evidence for an active and growing community
}

\author{
James A. Novitsky, Mary Catherine MacSween \\ Department of Biology, Dalhousie University, Halifax, Nova Scotia, Canada B3H 4J1
}

\begin{abstract}
Microbial biomass, heterotrophic activity, and growth rates were measured in sandy sediments from 2 very different beaches in Nova Scotia, Canada: a protected beach inside Halifax Harbor (HH), and an exposed, high energy beach along the coast (LT). SEM of sand grains revealed that the microbial cells from $\mathrm{HH}$ were predominantly cocci whereas the cells from LT were mostly rods. HH sand contained 3.8 times as many cells (direct count) and 6.9 times as much biomass (ATP) as did LT sand. Likewise, the heterotrophic uptake, rates of nucleic acid synthesis, and the rate of carbon production were all several times higher in HH sand than in LT sand. However, on a biomass-specific basis, both sediments had similar activity. Moreover, specific growth rates $\left(5.18 \mathrm{~d}^{-1}\right)$ were identical. The data indicate that size and total activity of the microbial population depend on the location of the sediment but that growth rate and per cell activity are apparently not affected by abrasion and shear stress.
\end{abstract}

\section{INTRODUCTION}

Sandy beaches, along with muddy sediments and salt marsh soils, make up a significant portion of the coastal marine ecosystem. As far as microbiology is concerned, of the 3 environments we know the least about sandy beaches. Ten years have passed since Meyer-Reil et al. (1978) identified sandy beach sediments as an environment with a significant and active microbial community, yet our knowledge is still limited to that study and a few others dealing primarily with enumeration and microscopic observations (Meadows \& Anderson 1966, Wiese \& Rheinheimer 1978, Koop \& Griffiths 1982, DeFlaun \& Mayer 1983).

Considered as a microbial habitat, a sandy beach has many advantages: a large amount of surface area for microbial colonization and adsorption of nutrients; a high porosity and thus an aerobic environment; generally higher temperatures than totally submerged environments; and a constant resupply of nutrients provided by wave action and tides. The obvious disadvantage to microbial colonization of sand grains, however, is the abrasion of the grains on high energy beaches

The object of the present study was to examine the microbial community of a high energy beach to determine its biomass, heterotrophic activity, and growth rate. It was hoped that these measurements would permit a preliminary assessment of the participation (if any) of the microbial community of sandy beaches in coastal marine ecology.

\section{MATERIALS AND METHODS}

Sampling. Sand and water samples were collected (October to December 1982, and again in May-June 1987) from 2 Nova Scotia, Canada, beaches: Halifax Harbor $(\mathrm{HH})$ and Lawrencetown (LT). Four sites from $\mathrm{HH}$ were utilized, all located within the city limits of Halifax at intervals along the shore-line of the Halifax Peninsula. One site from LT was utilized, an exposed length of sandy beach located ca $35 \mathrm{~km}$ northeast of Halifax. Surface sand was collected by hand from the water's edge (most closely corresponding to beach Zone 4, Fig. 1 from Koop \& Griffiths [1982]) in clean plastic containers. Water was collected at the same time in sterile plastic bottles. All samples were maintained near collection temperatures during transport to the laboratory. Prior to use all sand was sieved through a $2 \mathrm{~mm}$ sieve to remove the occasional rock or other large debris collected along with the sample.

Scanning Electron Microscopy (SEM). Sand grains were fixed in a solution containing $(\%, v / v)$ : glutaraldehyde, 2.5; filter-sterilized seawater, 85; and distilled water, 15. After fixation the grains were washed 
free of salt in a graded seawater-distilled water series. In preparation for critical point drying the grains were dehydrated in a graded ethanol series consisting of 10 min each in $10 \%, 25 \%, 50 \%, 75 \%$, and $100 \%$ ethanol The sand grains were critical point dried inside wettable porous polyethylene capsules (Taab Laboratory Equipment, Berkshire, England) using a Polaron Critical Point Drying Apparatus Model E3000. Once dried the grains were attached to SEM stubs using doublesided tape (Scotch No. 665) and sputter coated with gold-palladium. The samples were examined using a Bausch and Lomb ARL Nanolab 2000 microscope. In all, 20 stubs were examined with an average of 400 grains per stub; in total, detailed examination was undertaken for about 140 grains from each site. Micrographs were recorded on Kodak Panatomic X film using a Pentax K 100035 mm camera.

Direct microscopic cell counts. Epifluorescence microscopy after acridine orange staining was used for cell enumeration. A weighed portion of sand (2 to $3 \mathrm{~g}$ ) was suspended in $50 \mathrm{ml}$ of fixative solution (as above) and blended for $3 \mathrm{~min}$ in a Waring blender to remove cells adhering to the sand grains. Scanning electron microscopy of the sand grains after blending showed that this treatment was the minimum required to effectively remove all the cells. After appropriate dilution of the resulting supernatant with filter-sterilized seawater, the cells were stained and observed as described previously (Novitsky 1983).

ATP determinations. Ten subsamples from each sampling site were assayed for ATP content as follows. Five $\mathrm{ml}$ of wet, freshly-collected sand was added with immediate and thorough mixing to $15 \mathrm{ml}$ of cold $\mathrm{H}_{3} \mathrm{PO}_{4}$ $(1.47 \mathrm{M})$. After $30 \mathrm{~min}$ the ATP was extracted and measured as described previously (Novitsky \& Karl 1985). To correct for apparent and real losses of extractable ATP, internal standards were added to quintuplicate samples from both sites and processed in an identical manner.

Metabolic activity and growth measurements. Relative heterotrophic activity was measured by the uptake of $\left[\mathrm{U}-{ }^{14} \mathrm{C}\right]$ glutamic acid as previously described (Novitsky \& Karl 1985). DNA and RNA synthesis rates were determined by the uptake of $\left[2-{ }^{3} \mathrm{H}\right]$ adenine as described by Novitsky \& Karl (1985). All incubations were carried out at $5^{\circ} \mathrm{C}$, the in situ temperature at the time of collection. Carbon production was extrapolated from the rate of DNA synthesis by assuming that $1 \mathrm{pmol}$ of DNA is equivalent to $1236 \mathrm{pg}$ of DNA produced and that DNA accounts for $2 \%$ of total cell carbon. The mean microbial community specific growth rate was derived from the measured rate of DNA synthesis and the ATP biomass data, i.e. (doublings $\mathrm{d}^{-1}$ ) $\times 0.693$, assuming a DNA/ATP ratio of 5 . The rationale for this extrapolation is presented elsewhere (Karl \& Winn 1984).

\section{RESULTS}

The sampling sites were chosen for their contrasting characteristics: $\mathrm{HH}$ is sheltered and receives very little wave action whereas LT is exposed to high wave energy. In addition, the $\mathrm{HH}$ beaches are exposed to higher levels of organic matter due to the continuous discharge of untreated sewage into Halifax Harbor. The grain size analyses of both sediments, however, were similar. Sediment from both sites was wet sieved into 3 fractions: $850 \mu \mathrm{m}$ to $2 \mathrm{~mm} ; 250$ to $850 \mu \mathrm{m}$; and 75 to 250 um. The percentage (dry weight basis) respectively in each fraction, was: $37.3,54.2,8.5$ and $42.4,55.3,2.3$ for $\mathrm{HH}$ and LT respectively. For both sediments, less than $1 \%$ of the material passed the $75 \mu \mathrm{m}$ sieve. SEM observation of the grains revealed a gentle weathering of the $\mathrm{HH}$ grains with rounded corners and edges and rough, pitted surfaces. In contrast, the LT grains exhibited sharp corners, angular outcrops, and smooth surfaces. Also, portions of the HH grains were covered with what appeared to be amorphous detrital material which was absent from the LT samples (Fig. 1b, c).

Microbial colonization of sand grains from both sites was sparse when judged on a percentage of surface area basis. Microcolonies were rarely observed and single cells were usually found tucked into corners and crevices. Some grains showed no signs of colonization at all. Specific attachment mechanisms such as holdfasts were never observed. Polymer strands apparently used for attachment (Fig. 1d) were only infrequently observed; moreover, it was more common for the strands to be formed between cells rather than between cells and sand grains. The most notable difference between the cells from $\mathrm{HH}$ and LT was their shape. Cells on sand grains from HH (Fig. 1a, b) were generally spherical, 0.6 to $1.0 \mathrm{um}$ in diameter whereas cells on sand grains from LT (Fig. 1c, d) were generally rod shaped, 0.5 to $2.5 \mu \mathrm{m}$ in length and 0.2 to $0.4 \mu \mathrm{m}$ in width. Occasionally cells on HH grains were embedded in the detrital material (Fig. 1b) but usually they were found in proximity to, rather than within, these fields of detritus.

The total number of cells in $\mathrm{HH}$ sediment was $7.32 \times$ $10^{7} \pm 1.42 \times 10^{7}$ cells per $g$ dry sediment (mean \pm $95 \%$ confidence interval; average of 4 sites, $n=19$ ) and on LT sediment the total number was $1.91 \times 10^{7} \pm$ $2.76 \times 10^{6}$ cells per $\mathrm{g}$ dry sediment (mean $\pm 95 \%$ confidence interval; 1 site, $n=12$ ).

The average ATP content of the $\mathrm{HH}$ sediment [mean (SE) ; $n=10$ l expressed on a ng per wet $\mathrm{cm}^{3}$, dry $\mathrm{cm}^{3}$, and dry g basis was $72.18(5.45), 58.47(4.42)$, and 35.41 (2.67), respectively. The average ATP content of the LT sediment [mean (SE); $n=10$ ] expressed on a ng per wet $\mathrm{cm}^{3}$, dry $\mathrm{cm}^{3}$, and dry g basis was $10.15(0.19), 8.12$ (0.15), and $5.13(0.10)$, respectively. 

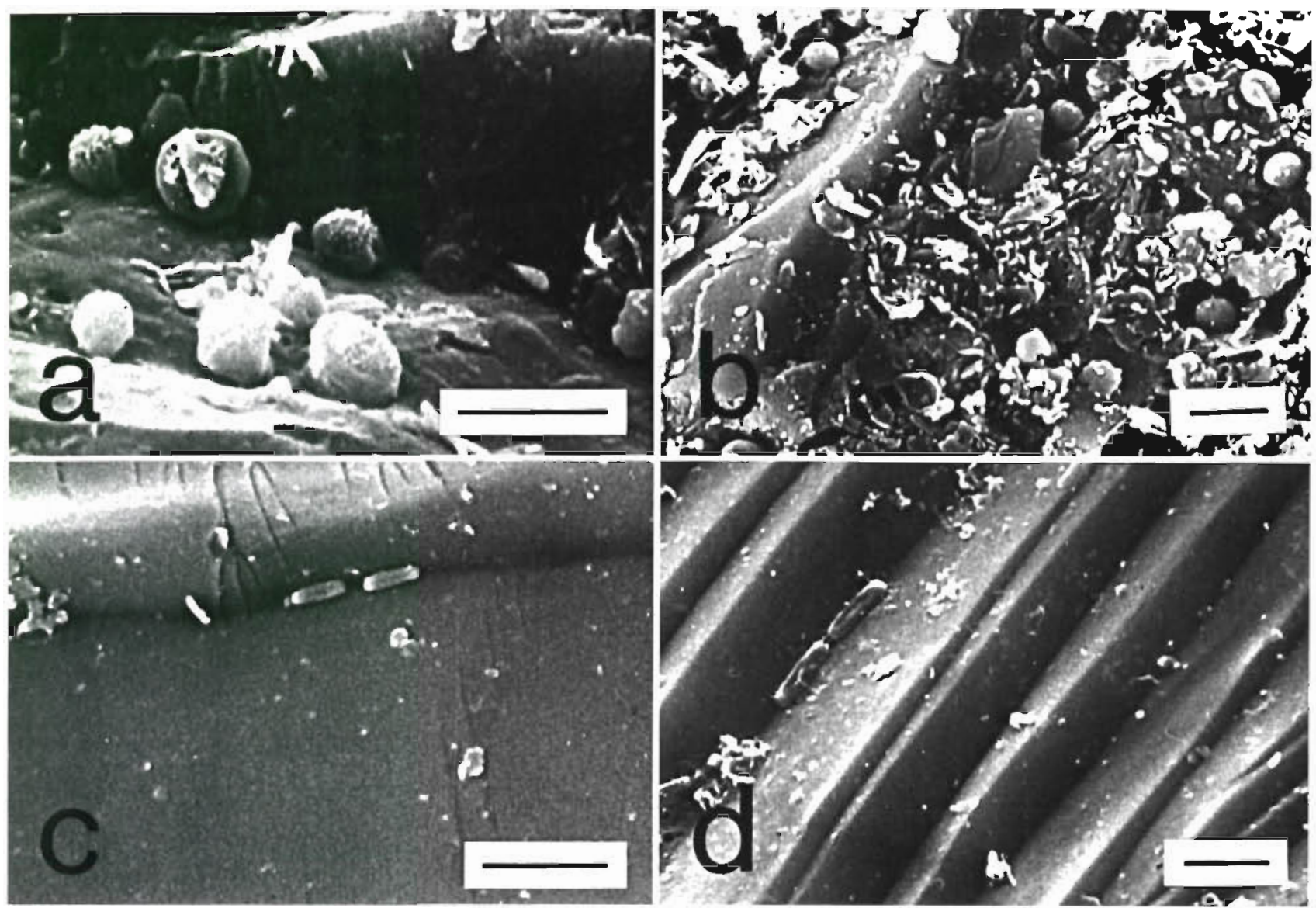

Fig. 1. Scanning electron micrographs of sand grains from 2 Nova Scotia beaches. (a, b) Halifax Harbor; (c, d) Lawrencetown Beach. Bars $=2 \mu \mathrm{m}$

The average rate of uptake of glutamic acid was 4.60 and $1.13 \mathrm{ng} \mathrm{g}^{-1} \mathrm{~h}^{-1}$ for the $\mathrm{HH}$ and LT sediment, respectively. When the sediment was gently washed with filter-sterilized seawater prior to the uptake assay, activity was reduced by $48.3 \%$ and $15.0 \%$ for the $\mathrm{HH}$ and LT sediments, respectively. Size fractionation experiments revealed that $56.3 \%$ of the heterotrophic activity was associated with the $850 \mu \mathrm{m}$ to $2 \mathrm{~mm}$ fraction while $41.2 \%$ and $2.5 \%$ was associated with the
$250 \mu \mathrm{m}$ to $850 \mu \mathrm{m}$ and $75 \mu \mathrm{m}$ to $250 \mu \mathrm{m}$ fractions, respectively. However, on a per gram of each individual fraction basis, the uptake activities were roughly equal with uptake rate ratios of $41.9: 23.5: 34.6$ for the largest to smallest size fractions, respectively.

The rates of DNA and RNA synthesis for both sediments along with the derived specific growth rates and carbon production values are shown in Table 1 . While the absolute rates of DNA and RNA synthesis and

Table 1. Nucleic acid synthesis rates and derived specific growth rates of microbial communities in Halifax Harbor (HH) and Lawrencetown (LT) sediments

\begin{tabular}{|c|c|c|c|c|c|c|c|}
\hline Site & \multicolumn{2}{|c|}{$\begin{array}{c}\text { Synthesis } \\
\text { (pmol g dry wt } t^{-1} h^{-1} \text { ) }\end{array}$} & $\begin{array}{l}\text { DNA: RNA } \\
\text { rate ratio }\end{array}$ & \multicolumn{2}{|c|}{$\begin{array}{l}\text { Biomass-specific rates } \\
\left(\mathrm{pmol} \text { ng of } \mathrm{ATP}^{-1} \mathrm{~h}^{-1} \text { ) }\right.\end{array}$} & $\begin{array}{l}\text { Carbon } \\
\text { production } \\
\left.\text { (ug } g \text { dry } w t^{-1} d^{-1}\right)\end{array}$ & $\begin{array}{c}\text { Specific growth } \\
\text { rate }^{\mathrm{b}} \\
\text { (per d) }\end{array}$ \\
\hline $\mathrm{HH}$ & 44.6 & 666.7 & 0.067 & 1.26 & 18.8 & 66.2 & 5.18 \\
\hline LT & 6.5 & 99.4 & 0.065 & 1.26 & 19.4 & 9.6 & 5.19 \\
\hline \multicolumn{8}{|c|}{$\begin{array}{l}\text { Carbon production was extrapolated from rates of DNA synthesis by assuming that } 1 \text { pmol of DNA is equivalent to } 1236 \text { pg of } \\
\text { DNA produced and that DNA is } 2 \% \text { total cell carbon } \\
\text { b Specific growth rate is doublings } \mathrm{d}^{-1} \times 0.693 \text {. Doublings } \mathrm{d}^{-1} \text { were calculated as carbon production/biomass carbon obtained } \\
\text { from ATP } \times 250\end{array}$} \\
\hline
\end{tabular}


carbon production are all several times higher for $\mathrm{HH}$ sediment, the biomass-specific rates and the specific growth rates are very similar.

\section{DISCUSSION}

Both sampling sites used in this study would be described by the lay observer as sandy beaches. Indeed, the grain size analyses bear out this observation. Microscopically, however, the sediments were quite different. Due to the gentle wave action and increased organic matter availability, the $\mathrm{HH}$ sand grains were noticeably weathered and many were covered with relatively thick layers of organic detritus. Still, the microbial cells tended to colonize only the cracks, crevices, and sheltered areas of the grains. This selective colonization has also been reported by others (Meadows \& Anderson 1966, Wiese \& Rheinheimer 1978, DeFlaun \& Mayer 1983). The LT grains, exposed to high wave energy, had sharp comers and smooth surfaces indicative of recent fractures and constant abrasion thus cleaning the surfaces. The working hypothesis at the onset of this study was that cells in this type of environment, if present at all, would possess specific attachment structures or glycocalyx fibers (Costerton et al. 1978, Costerton \& Irvin 1981) to adhere to the grains. However, the majority of observations did not support this hypothesis. How most of the cells remain attached to the sand is not known but possibilities include a polysaccharide 'glue' that was not seen by SEM, and physical entrapment in irregularlyshaped crevices. Large areas of grains from both sites were devoid of any colonization. Meadows \& Anderson (1966) also reported such patchiness while DeFlaun \& Mayer (1983) calculated that microbes colonized only 0.01 to $0.05 \%$ of the available surface area. While we did not specifically measure surface area in the present study, our estimate (less than $1 \%$ of the available area colonized) supports the conclusion of DeFlaun \& Mayer (1983) and Hargrave (1972) that bacterial colonization is not surface area limited. It must be pointed out, however, that SEM processing is a harsh treatment and may have destroyed some of the attachment structures or entire microcolonies. During preliminary studies several different preparation techniques were evaluated. The main difference among techniques was the collapse of cells with some dehydration techniques. While it is unlikely that our technique eliminated the majority of microcolonies and attachment structures, the possibility of some loss exists and therefore SEM data must be considered cautiously.

The total number of bacteria in the sediment (ca $10^{7}$ to $10^{8} \mathrm{~g}^{-1}$ ) from both the $\mathrm{HH}$ and LT sites was approximately equal to that determined by Koop \& Griffiths
(1982) for surface Zone 4 sand $\left(6 \times 10^{7} \mathrm{ml}^{-1}\right)$, less than that determined by Meadows \& Anderson (1966) (1 to $5 \times 10^{8} \mathrm{~g}^{-1}$ ), and much less than that determined by DeFlaun \& Mayer (1983) or Meyer-Reil et al. (1978) ( 1 to $5 \times 10^{9} \mathrm{~g}^{-1}$ ). The major reason for this discrepancy is probably the large variations in grain size, and thus surface area, of the sediments studied. Since microbial abundance is inversely related to grain size (Dale 1974), our low abundance figures may simple represent the relatively large portion of our sediments with a grain size $>850 \mu \mathrm{m}$. The microbial biomass as measured by ATP was also lower in HH and LT sediment than that measured in the aforementioned studies. The $\mathrm{HH}$ sediment biomass was almost 7 times that measured in LT sediment, possibly reflecting the larger amount of organic material available in Halifax Harbor, although Rublee \& Dornseif (1978) found no correlation between microbial biomass and the organic content of salt marsh sediments. The number of cells per gram of $\mathrm{HH}$ sediment, however, was only 3.8 times the number recorded for LT sediment. Assuming that all the microbial biomass is bacterial, the cells in $\mathrm{HH}$ sediment would not only have to be more numerous but would have to be richer in ATP (and probably larger) as well. Using the range of sizes for cells measured in the SEM study, the ranges of volume per cell were calculated to be 0.11 to 0.52 and 0.01 to $0.30 \mu^{3}$ for the $\mathrm{HH}$ and LT communities, respectively. Although specific counts of protozoa and algae were not made in this study it is unlikely that these groups make up a large portion of the microbial population. For nearby Nova Scotia sediments, protozoa and algae constitute less than $1 \%$ of the sediment microbial population (Johnson \& Novitsky unpubl.).

The heterotrophic uptake of glutamate was also higher for $\mathrm{HH}$ than LT sediments, most likely reflecting the increased biomass. Since the actual rate of glutamate uptake can only be calculated knowing the amount of in situ glutamate (not determined in this study), the figures reported here are minimum rates and can only be accurately used for comparison purposes. In order to standardize the heterotrophic measurement between both sites, both sediments were suspended in the same water (LT). Reports vary greatly on the number of cells actually 'attached' to sediment particles because many different functional definitions have been applied. Rather than examine numbers, we decided to determine the amount of activity that would remain with the sediment particles after gentle washing. Not surprisingly, the heterotrophic activity of $\mathrm{HH}$ sediment was reduced almost by half after gentle washing. In contrast, the activity of LT sediment was reduced by only $15 \%$ It is impossible to conclude from these data whether a greater percentage of the LT community is attached, or if the strong wave action 
continually removes the unattached cells from the pore spaces of the sediment. Regardless, a large number of active cells are able to attach to, and remain attached to, sand grains exposed to a large amount of abrasion.

Measuring the heterotrophic activity associated with the various size fractions of the sediment revealed an activity distribution that roughly matched the size distribution. When the activity was expressed on a per gram of each fraction basis, it became quite clear that the microbes do not attach preferentially to a specific grain size. DeFlaun \& Mayer (1983) reported no specific size preference except that bacteria do not tend to colonize grains $<10 \mu \mathrm{m}$, an insignificant size fraction in HH and LT sediments. In addition, Cammen (1982) found no predictable relationship between numbers of bacteria and particle size within or among 4 diverse marine sediments.

Both DNA and RNA synthesis rates were elevated in the $\mathrm{HH}$ sediment compared to the LT sediment but were significantly lower than those reported for a submerged, subtropical, sandy sediment (Novitsky \& Karl 1985). However, on a biomass-specific, and presumably a per-cell basis, the $\mathrm{HH}$ nucleic acid synthesis rates were equal to those measured at LT, and both Nova Scotia sites were actually higher than the subtropical sediment (Novitsky \& Karl 1985). The elevated synthesis rate at the $\mathrm{HH}$ site resulted in a higher carbon production value but the specific growth rates at both sites were equal and comparable to the subtropical sediment (Novitsky \& Karl 1985). These results suggest that standing stock biomass is controlled by organic carbon input but that per cell activity and the specific growth rate are independent of organic carbon input. These are essentially the same conclusions reported by Novitsky \& Karl (1985) in a study of subtropical, coastal, sandy sediments. It is interesting that sandy sediments from 3 widely differing environments show similar patterns. A major difference, however, is the lower DNA:RNA synthesis ratio observed for the Nova Scotia sediments. High RNA synthesis rates relative to DNA synthesis rates have been taken to indicate higher metabolic activity relative to growth. This may be caused by unbalanced growth, i.e., biomass production without concomitant growth. Since the exact metabolic state (growing, non-growing, dormant, injured, etc.) of each cell within the microbial populations is unknown, differences between the nucleic acid synthesis ratios may reflect differences between the populations, possibly due to environmental factors. In the case of Nova Scotia and subtropical sediments an obvious difference is temperature but other factors may also influence the state of the microbial population.

In summary, the data presented here indicate that This article was presented by Dr M. R. Lewis, Washington, D.C., USA the individual cells of a microbial beach sand community are able to withstand the abrasion and shear stress associated with a high energy environment. Although the microbial community itself was smaller than a counterpart on a low energy, highly organic beach, the individual cells exhibited the same growth rate and biomass production. It is apparent that the microbial community has adapted adequately to what might be considered an extreme environment, representing a major portion of the global coastal ecosystem.

Acknowledgements. We thank C. Mason for help with electron microscopy and J. Bugden for excellent technical assistance. This research was funded by grant A-6548 from the National Research Council of Canada.

\section{LITERATURE CITED}

Cammen, L. M. (1982). Effect of particle size on organic content and microbial abundance within four marine sediments. Mar. Ecol. Prog. Ser. 9: 273-280

Dale, N. G. (1974). Bacteria in intertidal sediments: factors related to their distribution. Limnol. Oceanogr. 19: 509-518

DeFlaun, M. F. Mayer, L. M. (1983). Relationships between bacteria and grain surfaces in intertidal sediments. Limnol. Oceanogr. 28: 873-881

Costerton, J. W., Geesey, G. G., Cheng, K.-J. (1978). How bacteria stick. Sci. Amer 238: 86-95

Costerton, J. W., Irvin, R. T. (1981). The bacterial glycocalyx in nature and disease. Ann. Rev. Microbiol. 35: 299-324

Hargrave, B. T. (1972). Aerobic decomposition of sediment and detritus as a function of particle surface area and organic content. Limnol. Oceanogr. 17: 583-596

Karl, D. M., Winn, C. D. (1984). Adenine metabolism and nucleic acid synthesis: applications to microbial oceanography. In: Hobbie, J. E., Williams, P. J. leB. (eds.) Heterotrophic activity in the sea. Plenum Publishing Corp., New York, p. 197-215

Koop, K. Griffiths, C. L. (1982). The relative significance of bacteria, meio- and macrofauna on an exposed sandy beach. Mar. Biol. 66: 295-300

Meadows, P. S., Anderson, J. G. (1966). Microorganisms attached to marine and freshwater sand grains. Nature, Lond. 212: 1059-1060

Meyer-Reil, L.-A., Dawson, R., Liebezeit, G., Tiedge, H. (1978). Fluctuations and interactions of bacterial activity in sandy beach sediments and overlying waters. Mar. Biol. 48: $161-171$

Novitsky, J. A. (1983). Heterotrophic activity throughout a vertical profile of seawater and sediment in Halifax Harbor, Canada. Appl. environ. Microbiol. 45: 1753-1760

Novitsky, J. A., Karl, D. M. (1985). Influence of deep ocean sewage outfalls on the microbial activity of the surrounding sediment. Appl, environ. Microbiol. 50: 1464-1473

Rublee, P. A., Dornseif, B. E. (1978). Direct counts of bacteria in the sediments of a North Carolina salt marsh. Estuaries 1: 188-191

Wiese, W., Rheinheimer, G. (1978). Scanning electron microscopy and epifluorescence investigation of bacterial colonization of marine sand sediments. Microbiol. Ecol. 44 175-188

Revised version accepted: November 25, 1988 